\title{
Differential resistance reaction of maize genotypes to maize stem borer (Chilo partellus Swinhoe) at Chitwan, Nepal
}

\author{
Ghanashyam Bhandari ${ }^{*}$, Buddhi Bahadur Achhami, \\ Saraswati Neupane and Sheela Devi Sharma \\ National Maize Research Program, Rampur, Chitwan \\ *Corresponding author email: bhandarigb_1978@yahoo.com
}

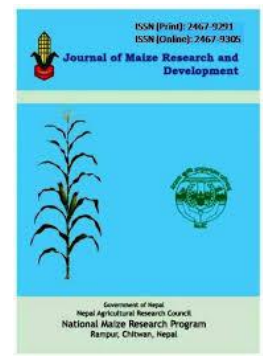

Received: September 2016; Revised: October 2016; Accepted: November 2016

\begin{abstract}
Maize stem borer (MSB), Chilo partellus Swinhoe, Lepidoptera: Pyralidae is one of the most important insect pest of maize in Nepal. Host plant resistance is the cost-effective, ecologically sound and stable approach to reduce damage by stem borers. Forty four maize genotypes were screened for resistance to maize stem borer at the research field of National Maize Research Program, Rampur during spring seasons (March to June) of two consecutive years 2013 and 2014. The maize genotypes were evaluated in randomized complete block design with three replications and data were collected on foliar damage rating, tunnel length and number of exit holes made by the borer. The foliar damage and tunnel length damage were significant for genotypes for both the years. The exit holes were not significant in 2013 but significant in 2014 ranging from 2-6 scale. The foliar rating ranged from 2 to 5.5 in 2013 and 1.1 to 4.5 in 2014 on a 1-9 rating scale. The highly resistant genotypes ( $<2.0$ score) were R-POP-2 and RML-5/RML- 8 . The tunnel length ranged from 3.2 to $22.5 \mathrm{~cm}$ in 2013 and 4.2 to $20.4 \mathrm{~cm}$ in 2014 on $0->10 \mathrm{~cm}$ scale. The least susceptible genotypes $(<5 \mathrm{~cm})$ were RampurSO3F8, RampurSO3FQ02 and RampurS10F18. The genotypes having least exit holes (2.0) in 2014 were RampurSO3F8, RampurSO3FQ02, RampurS10F18. Thus less damage parameters were observed in R-POP-2, RML-5/RML-8, RampurSO3F8, RampurSO3FQ02 and RampurS10F18 and therefore they can be used as parents or as sources of resistance in breeding program.
\end{abstract}

Key words: Breeding program, Chilo partellus, damage, Host resistance, Maize

Correct citation: Bhandari, G.S., Achhami, B.B., Neupane, S., \& Sharma, S. (2016). Differential resistance reaction of maize genotypes to maize stem borer (Chilo partellus Swinhoe) at Chitwan, Nepal. Journal of Maize Research and Development, 2(1), 133-143, doi.: http://dx.doi.org/10.3126/jmrd.v2i1.16224 


\section{INTRODUCTION}

Maize (Zea mays L.) is the second most important staple food crop in Nepal. It is the major crop among the hilly' people and is increasingly being used as animal and poultry feed as well. Maize plants are affected by biotic and abiotic factors that limit the grain production per unit area (Acchami et al., 2015). Among insect pests, MSB, Chilo partellus Swinhoe, Lepidoptera: Pyralidae) is one of the most devastating insect pest in maize production (Neupane et al., 1984; Jyoti \& Shivakoti, 1992; Songa et al., 2002, Sharma \& Gautam, 2010).

The MSB can cause 20 to $80 \%$ plant damage (Thakur et al., 2013; Neupane et al., 1984a). Similarly, Sharma and Gautam (2010) found that stem borer controlled field yielded 28\% more harvest of grain yield as compared to uncontrolled one. It attacks maize plants from whorl - tomaturity stage, by creating entry point for disease causing organisms. Leaf damage, stem tunneling, dead heart, peduncle breakage, stunting and white head are the major damages caused by this insect pest, sometimes resulting heavy yield loss up to 83\% (Chatterji et al., 1969; Kant et al., 1994; Sekhon \& Kanta, 1994).

The maize especially grown in mid-hills, foot-hills and Terai below 1,700 m altitude, is often damaged by this pest (Attri \& Sharma, 1968). In the Inner Terai, the subtropical region of Nepal, this pest passes through five generations in a year and pest activity reaches to peak during summer (July-August) causing maximum damage to rainy maize every year (Coppel et al., 1985).

The use of resistant varieties is environmentally safe, economically feasible and socially acceptable approach of pest management. Resistant materials can be used in breeding programs in host plant resistance studies or directly in variety testing prior to recommendation or release. Such type of information is not sufficient in our country therefore; this study was carried out in order to identify resistance genotypes against MSB.

\section{MATERIALS AND METHOD}

\section{Plant materials}

Field experiments were conducted to identify the sources of resistance for maize stem borer in maize genotypes during 2013 and 2014 spring seasons at National Maize Research Program, Chitwan, Nepal. An experiment composed of 44 elite maize genotypes during 2013 and 51 elite genotypes during 2014 that were pulled from Open Pollinated Varieties (OPV), Quality Protein Maize (QPM) and Hybrids including Rampur composite, Arun 2, Deuti, Posilo makai 1 and Rampur hybrid-2 as a standard checks were evaluated in RCB design with three replications to find out the resistance source of maize stem borer. The experimental site has the latitude of $27^{\circ} 40^{\prime} \mathrm{N}$, longitude of $84^{\circ} 19^{\prime} \mathrm{E}$ and altitude of $228 \mathrm{~m}$ mean sea level. For each genotype, two rows of five meter long, and the crop geometry $60 \times 25 \mathrm{~cm}$ were maintained. The individual plot area was $6 \mathrm{~m}^{2}$. The recommended package of practices was followed during crop growth according to recommendations given by National Maize Research Program (NMRP), Rampur, Chitwan. 


\section{Data collection}

Plant damage percentage, number of exit hole and stem tunneling were taken from the tested genotypes to evaluate the resistance level of maize genotypes against MSB.

\section{Plant damage percentage}

During the vegetative stage (V8 leaf stage) and just before tasselling stage (V12 leaf stage) plant damage percentage was estimated by counting healthy and damage plants of all evaluated genotypes. For this five sampled plants were counted visually after removing the intact leaves on stem for the exit holes made by stem borer and then proceed for tunnel length measurement. Then the sampled plants were dissected longitudinally, and measurement taken on groove made by stem borer. Plant damage percent was simply calculated by using the formula given below.

Damage percentage $(\%)=\frac{\text { Number of infected plant }}{\text { Total number of plant }} \times 100$

Table 1. Stem borer leaf damage scoring scale (1-9)

\begin{tabular}{lll}
\hline Scale & Description & Host reaction \\
\hline 1 & No visible leaf feeding damage & Highly resistant (RH) \\
2 & Few pin holes on older leaves & Resistant (R) \\
3 & Several shot-holes injury on a few leaves & Resistant (R) \\
4 & Several shot-hole injuries common on several leaves or & Moderately resistant (MR) \\
& small lesions & \\
5 & Elongated lesions (> 2 cm long) on a few leaves & Moderately resistant (MR) \\
6 & Elongated lesions on several leaves & Susceptible (S) \\
7 & Several leaves with elongated lesions or tattering & Susceptible (S) \\
8 & Most leaves with elongated lesions or severe tattering & Highly susceptible (HS) \\
9 & Plant dying as a result of foliar damage & Highly susceptible (HS) \\
\hline
\end{tabular}

\section{Weather data}

Source: Ampofo and Saxena (1987)

The weather parameters taken during the experiments were as below;

Table 2. Weather data of cropping season during 2013

\begin{tabular}{lllll}
\hline Month & Max temp. $\left({ }^{\mathbf{O}} \mathbf{C}\right)$ & Min temp. $\left({ }^{\mathbf{O}} \mathbf{C}\right)$ & RH (\%) & Rainfall (mm) \\
\hline February & 25.7 & 7.01 & 91.15 & 0.00 \\
March & 31.86 & 12.38 & 96.35 & 0.95 \\
April & 34.56 & 15.96 & 85.31 & 1.14 \\
May & 34.97 & 23.07 & 88.00 & 12.12 \\
June & 34.2 & 26.33 & 93.18 & 22.25 \\
\hline
\end{tabular}


Journal of Maize Research and Development (2016) 2 (1): 133-143

ISSN: 2467-9291 (Print), 2467-9305 (Online)

DOI: http://dx.doi.org/10.3126/jmrd.v2i1.16226

Table 3. Weather data of cropping season during 2014

\begin{tabular}{lllll}
\hline Month & Max temp. $\left({ }^{\mathbf{0}} \mathbf{C}\right)$ & Min temp. $\left({ }^{\mathbf{0}} \mathbf{C}\right)$ & RH $(\%)$ & Rainfall (mm) \\
\hline February & 22.90 & 12.58 & 84.46 & 0.73 \\
March & 30.62 & 17.27 & 76.96 & 0.32 \\
April & 36.66 & 21.46 & 66.53 & 0.13 \\
May & 37.06 & 23.85 & 73.80 & 3.23 \\
June & 35.26 & 26.91 & 92.39 & 12.98 \\
\hline
\end{tabular}

\section{Tunnel length and exit hole measurement}

Five plants from each tested genotypes were sampled for tunnel length and exit-hole measurement. Data related to plant height and tunnel length were noted and their mean was calculated. Keeping in view, data related to stem tunnel length was measured under following 3 categories (Rajasekhar \& Srivastav, 2013)

Table 4. Tunnel length and exit hole measurement scale

\begin{tabular}{lll}
\hline S.N. & Rating scale & Host reaction \\
\hline 1 & $0-5$ & Least susceptible \\
2 & $5-10$ & Moderately Susceptible \\
3 & $>10$ & Highly Susceptible \\
\hline
\end{tabular}

\section{Data analysis}

Using statistical software, Excel and GENSTAT, all collected data were analyzed. The significant differences between treatments were estimated at 5\% probability level using least significant difference (LSD) test.

\section{RESULTS AND DISCUSSION}

\section{Foliar damage score}

The foliar damage was significant for genotypes in both years. The infestation level of MSB was observed comparatively higher in 2013 than 2014. The results indicated that none of the germplasm was highly resistant at whorl stage during both of the experiment years. The foliar rating ranged from 2 to 5.5 in 2013 and 1.1 to 4.5 in 2014 on a $1-9$ rating scale. The highly resistant genotypes ( $<2.0$ score) were R-POP-2 and RML-5/RML-8. In 2013 the majority of genotypes showed resistant reaction (1-3 score) except EEYC-1 (4.2 score), Khumal yellow/Pool 17 (4.2 score), RML-4/RML-17 (4.3 score), and RML 4/NML-2 (4.3 score). Siddiqui et al. (1996) evaluated the maize varieties for resistance on the basis of leaf injury. Sharma and Sharma (1992) reported the resistance in maize plants on the basis of lowest leaf damage. Range of percentage damage varied from 23.1 to $61.7 \%$ at knee high stage as compared to reproductive stage (9.6-31.7\%). Kumar and Asino (1993) considered the parameters like leaf damage, dead heart and stalk damage on maize by MSB to distinguish the resistant and susceptible genotypes. Leaf toughness, trichome density, and stem penetrometer resistance are important forms of 
physical resistance (antibiosis) against maize stem borers while stem sugar contents are reported to promote stem borer feeding in cereals (Padhi, 2004; Sarwar, 2012). Relatively higher level of secondary metabolites such as benzoxazinoid DIMBOA (2, 4 dihydroxy-7-methoxy- $(2 \mathrm{H})-1,4-$ benzoxazin-3 (4H)-one) contain maize plants have resistance properties to MSB infestation (Klun et al., 2009; McMullen et al., 2009). Thus, the similar secondary metabolites produced by plants in our experimental field might be the reasons of variation in plant damage percentage among the tested genotypes. In 2014, most of the genotypes showed less resistance reaction (1-3 score) except Khumal yellow/Pool 17 (4.5 score), Arun-4 (4.3 score), RampurSO3F8 (4.2 score), RML-4/RML-17 (4.3 score) and RML-78/RML-36 (3.8 score). Percent of damage plants per plot was observed higher in younger stages than older stage. Range of percentage damage varied from 23.5 to $50.3 \%$ at knee high stage as compared to reproductive stage (11.2-33.4\%).

\section{Tunnel length measurement}

The tunnel length damage was significant for genotypes during both the years. The tunnel length injury ranged from 3.2 to $22.5 \mathrm{~cm}$ in 2013 and 4.2 to $20.4 \mathrm{~cm}$ in 2014 on $0->10 \mathrm{~cm}$ scale. The least susceptible genotypes $(<5 \mathrm{~cm})$ were RampurSO3F8, RampurSO3FQ02 and RampurS10F18. But the intensity of tunnel length damage observed was higher in 2013 than 2014. In 2013, the genotypes SOOTLYQ-B, SO3TLYQ-AB-01, S99TLYQ-AB showed moderately susceptible range $(5-10 \mathrm{~cm})$ where as EEYC-1, Narayani, Khumal yellow/Pool 17 and COTAXLA 0024 had maximum damage at a range of $16-23 \mathrm{~cm}$. In the year 2014, Rampur SO3F8, RampurSO3FQ02 Rampur S10F18 reacted less susceptible $(4.2-4.6 \mathrm{~cm})$ followed by S99TLYQ-AB, S99TLYQ-B, S03TLYQ-AB-02 S00TLYQ-AB S00TLYQ-B having moderate susceptibility (5.7-7.9 cm) and RML-4/RML-17, RML-95/RML-96, RML-87/RL-105 with the susceptible range of $6.8-8.8 \mathrm{~cm}$. These tunnel length results were similar to the results recorded by Lela and Srivastav (2013). Kumar (1988) reported that stem-tunneling damage had a significant influence on maize plant growth and development. Likewise, Odiyi (2007) and Singh et al. (2011) noticed that for the loss in maize grain yield, the effect of stem tunneling was greater than that of leaf feeding.

\section{Exit holes}

The results on exit holes revealed non-significant reaction in 2013 but significant in 2014 ranging from 2-6 scale. In 2014, the genotypes having least exit holes (2.0) were RampurSO3F8, RampurSO3FQ02 and RampurS10F18. These results were similar to the results reported by Munyri et al. (2013).

Table 5. Response of maize genotypes to maize stem borer during spring seasons of 2013 at Rampur, Chitwan

\begin{tabular}{|c|c|c|c|c|c|c|c|c|c|}
\hline \multirow[t]{2}{*}{ SN. } & \multirow[t]{2}{*}{ Genotypes } & \multicolumn{2}{|c|}{ Score $(0-9)$ scale } & \multirow{2}{*}{$\begin{array}{l}\text { Mean } \\
\text { score }\end{array}$} & \multicolumn{2}{|c|}{$\%$ damage } & \multirow{2}{*}{$\begin{array}{l}\text { Mean } \\
\text { damage } \\
(\%)\end{array}$} & \multirow{2}{*}{$\begin{array}{l}\text { Tunnel } \\
\text { length } \\
(\mathrm{cm})\end{array}$} & \multirow{2}{*}{$\begin{array}{l}\text { Exit } \\
\text { holes } \\
\text { (no.) }\end{array}$} \\
\hline & & $\begin{array}{l}\text { Whorl } \\
\text { stage }\end{array}$ & $\begin{array}{l}\text { Tunneling } \\
\text { stage }\end{array}$ & & $\begin{array}{l}\text { Whorl } \\
\text { stage }\end{array}$ & $\begin{array}{l}\text { Tunneling } \\
\text { stage }\end{array}$ & & & \\
\hline \multicolumn{10}{|c|}{ Open pollinated varieties } \\
\hline 1 & Across 9331 & 3.0 & 2.0 & 2.5 & 31.2 & 18.4 & 24.8 & 10.7 & 1.5 \\
\hline 2 & $\begin{array}{l}\text { Across } 942 \times \text { Across } \\
9944\end{array}$ & 3.4 & 2.3 & 2.8 & 34.6 & 20.3 & 27.4 & 14.2 & 2.3 \\
\hline
\end{tabular}


Journal of Maize Research and Development (2016) 2 (1): 133-143

ISSN: 2467-9291 (Print), 2467-9305 (Online)

DOI: http://dx.doi.org/10.3126/jmrd.v2i1.16226

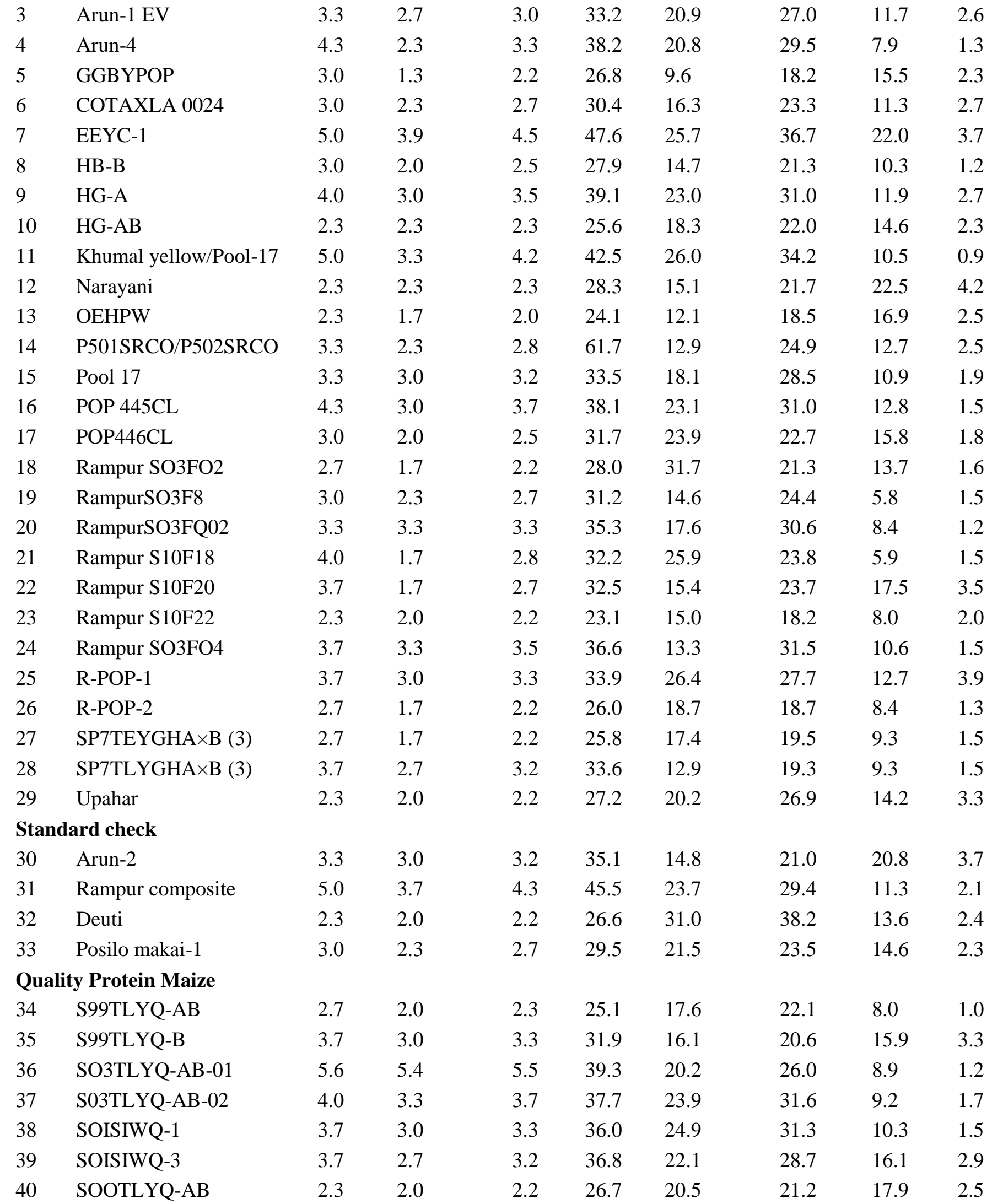


Journal of Maize Research and Development (2016) 2 (1): 133-143

ISSN: 2467-9291 (Print), 2467-9305 (Online)

DOI: http://dx.doi.org/10.3126/jmrd.v2i1.16226

\begin{tabular}{llllllllll}
41 & SOOTLYQ-B & 3.7 & 2.0 & 2.8 & 36.9 & 15.7 & 27.8 & 6.9 & 1.8 \\
$\begin{array}{l}\text { Hybrids } \\
42\end{array}$ & RML-4/RML-17 & 4.7 & 4.0 & 4.3 & 41.9 & 21.0 & 35.4 & 8.1 & 2.1 \\
43 & RML-32/RML-17 & 3.7 & 2.7 & 3.2 & 34.4 & 11.3 & 28.2 & 3.2 & 3.5 \\
44 & RML 4/NML-2 & 5.0 & 3.7 & 4.3 & 49.3 & 18.8 & 40.4 & 7.0 & 1.4 \\
\hline$\quad$ Grand Mean & 3.42 & 2.51 & 2.97 & 33.23 & 19.64 & 26.43 & 12.01 & 2.22 \\
& F-test & $*$ & $*$ & $*$ & $*$ & $*$ & $*$ & $*$ & $\mathrm{~ns}$ \\
$\quad$ CV\% & 45.6 & 45.3 & 41.3 & 47.6 & 34.0 & 36.7 & 60.0 & 66.0 \\
\hline
\end{tabular}

Table 6. Response of maize genotypes to maize stem borer during spring seasons of 2014 at Rampur, Chitwan

\begin{tabular}{|c|c|c|c|c|c|c|c|c|c|}
\hline \multirow[t]{2}{*}{ SN } & \multirow[t]{2}{*}{ Genotypes } & \multicolumn{2}{|c|}{ Score (0-9)scale } & \multirow{2}{*}{$\begin{array}{l}\text { Mean } \\
\text { Score }\end{array}$} & \multicolumn{2}{|c|}{$\%$ damage } & \multirow{2}{*}{$\begin{array}{l}\text { Mean } \\
\text { - damage } \\
(\%)\end{array}$} & \multirow{2}{*}{$\begin{array}{l}\text { Tunnel } \\
\text { length } \\
\text { (cm) }\end{array}$} & \multirow{2}{*}{$\begin{array}{l}\text { Exit } \\
\text { holes } \\
\text { (no) }\end{array}$} \\
\hline & & $\begin{array}{l}\text { Knee } \\
\text { high } \\
\text { stage }\end{array}$ & $\begin{array}{l}\text { Tasselling } \\
\text { stage }\end{array}$ & & $\begin{array}{l}\text { Knee } \\
\text { high } \\
\text { stage }\end{array}$ & $\begin{array}{l}\text { Tasselling } \\
\text { stage }\end{array}$ & & & \\
\hline \multicolumn{10}{|c|}{ Open Pollinated Varieties } \\
\hline 1 & Across 9331 & 3.8 & 2.4 & 3.1 & 42.8 & 27.3 & 35.0 & 9.0 & 3 \\
\hline 2 & $\begin{array}{l}\text { Across } 9942 \times \text { Across } \\
9944\end{array}$ & 3.3 & 2.1 & 2.7 & 36.8 & 23.1 & 29.9 & 9.7 & 4 \\
\hline 3 & Arun-1 EV & 3.0 & 2.1 & 2.5 & 33.8 & 23.2 & 28.5 & 10.3 & 2 \\
\hline 4 & Arun-4 & 4.3 & 1.3 & 2.8 & 47.6 & 15.1 & 31.3 & 15.1 & 4 \\
\hline 5 & BGBYPOP & 2.4 & 1.8 & 2.1 & 26.9 & 20.6 & 23.7 & 10.9 & 3 \\
\hline 6 & COTAXLA 0024 & 3.2 & 1.2 & 2.2 & 35.6 & 13.5 & 24.5 & 16.6 & 4 \\
\hline 7 & EEYC-1 & 5.0 & 4.1 & 4.5 & 38.2 & 13.9 & 26.0 & 13.1 & 2 \\
\hline 8 & HG-B & 3.2 & 1.4 & 2.3 & 35.5 & 15.6 & 25.5 & 13.4 & 5 \\
\hline 9 & HG-A & 4.1 & 1.8 & 3.0 & 46.1 & 20.3 & 33.2 & 12.8 & 4 \\
\hline 10 & HG-AB & 4.2 & 1.7 & 2.9 & 46.6 & 18.8 & 32.7 & 14.8 & 5 \\
\hline 11 & Khumal yellow/Pool-17 & 4.5 & 1.8 & 3.2 & 50.3 & 20.5 & 35.4 & 20.4 & 4 \\
\hline 12 & Narayani & 4.1 & 2.6 & 3.4 & 46.0 & 29.1 & 37.5 & 9.1 & 3 \\
\hline 13 & OEHPW & 2.9 & 1.6 & 2.2 & 32.3 & 18.0 & 25.1 & 11.9 & 4 \\
\hline 14 & P501SRCO/P502SRCO & 3.1 & 1.8 & 2.4 & 34.5 & 19.9 & 27.2 & 15.6 & 4 \\
\hline 15 & POP 445C1 & 3.7 & 2.2 & 3.0 & 41.5 & 24.5 & 33.0 & 8.7 & 3 \\
\hline 16 & POP446C1 & 3.0 & 1.7 & 2.4 & 33.1 & 19.7 & 26.4 & 8.3 & 3 \\
\hline 17 & Rampur SO3FO2 & 2.7 & 2.0 & 2.3 & 30.0 & 22.5 & 26.2 & 11.8 & 5 \\
\hline 18 & RampurSO3F8 & 4.2 & 2.5 & 3.3 & 46.4 & 28.2 & 37.3 & 4.2 & 2 \\
\hline 19 & RampurSO3FQ02 & 2.9 & 1.8 & 2.3 & 32.4 & 19.9 & 26.1 & 4.4 & 2 \\
\hline 20 & Rampur S10F18 & 3.0 & 1.6 & 2.3 & 33.8 & 18.1 & 25.9 & 4.6 & 2 \\
\hline 21 & Rampur S10F20 & 3.6 & 1.4 & 2.5 & 39.8 & 16.3 & 27.9 & 9.1 & 4 \\
\hline 22 & Rampur S10F22 & 2.6 & 2.8 & 2.7 & 29.5 & 31.4 & 30.4 & 14.2 & 6 \\
\hline 23 & Rampur SO3FO4 & 3.7 & 2.5 & 3.1 & 41.5 & 28.0 & 34.7 & 13.9 & 6 \\
\hline 24 & R-POP-1 & 2.2 & 1.2 & 1.7 & 24.7 & 13.9 & 19.2 & 14.2 & 5 \\
\hline
\end{tabular}


Journal of Maize Research and Development (2016) 2 (1): 133-143

ISSN: 2467-9291 (Print), 2467-9305 (Online)

DOI: http://dx.doi.org/10.3126/jmrd.v2i1.16226

$\begin{array}{ll}25 & \text { R-POP-2 } \\ 26 & \text { SP7TEYGHA×B (3) } \\ 27 & \text { SP7TLYGHA×B (3) } \\ 28 & \text { Upahar }\end{array}$

Quality Protein Maize

$\begin{array}{ll}29 & \text { S99TLYQ-AB } \\ 30 & \text { S99TLYQ-B } \\ 31 & \text { S03TLYQ-AB-01 } \\ 32 & \text { S03TLYQ-AB-02 } \\ 33 & \text { S01SIWQ-1 } \\ 34 & \text { S01SIWQ-3 } \\ 35 & \text { S00TLYQ-AB } \\ 36 & \text { S00TLYQ-B }\end{array}$

\section{Hybrid}

37 RML-4 /RML-17

38 RML-32/RML-17

39 RML-95/RML-96

40 RML-87/RL-105

41 RML-57 /RML-6

42 KYM-33/KYM-35

43 RL-180/RL-105

44 RL150/RL-111

45 RML-5 /RML-8

46 RML-78 /RML-36

47 RML-86 /RML-96

\section{Standard check}

\begin{tabular}{llcccccccc}
48 & Arun-2 & 2.9 & 1.6 & 2.2 & 32.2 & 17.7 & 24.9 & 8.5 & 3 \\
49 & Poshilo Makai-1 & 3.0 & 2.6 & 2.8 & 33.9 & 29.5 & 31.7 & 9.1 & 2 \\
50 & Rampur Composite & 4.2 & 2.4 & 3.3 & 46.6 & 27.0 & 36.8 & 16.8 & 5 \\
51 & Rampur Hybrid-2 & 3.7 & 1.9 & 2.8 & 40.7 & 21.0 & 30.8 & 7.7 & 3 \\
\hline & Grand Mean & 3.4 & 1.9 & 2.6 & 37.4 & 21.1 & 29.2 & 10.9 & 4 \\
& F-test & $*$ & $*$ & $*$ & $*$ & $*$ & $*$ & $*$ & $*$ \\
& CV\% & 44 & 47 & 35.4 & 44 & 47 & 35.4 & 66.1 & 63 \\
\hline
\end{tabular}

\section{Correlation among the parameters}

The correlation coefficients between visual damage score and number of exit holes was positive and high (0.98). Exit hole and tunnel length (0.87), visual damage score and tunnel length (0.83) were highly correlated. Correlation between damage percentage and tunnel length (0.16), damage percentage and exit hole (0.24), visual damage percentage and plant damage percentage (0.34) were comparatively less in 2013. Correlation coefficient between visual 
Journal of Maize Research and Development (2016) 2 (1): 133-143

ISSN: 2467-9291 (Print), 2467-9305 (Online)

DOI: http://dx.doi.org/10.3126/jmrd.v2i1.16226

damage score and number of exit hole (0.98), tunnel length and number of exit holes (0.93) and visual score and tunnel length (0.90) were positively higher. But, lower degree of correlation between damage percentage and tunnel length (0.14), damage percentage and number of exit hole (0.18), visual damage percentage and plant damage percentage (0.26) were observed in 2014.

\section{CONCLUSION}

The overall results ascertained the variability of resistance reaction among maize germplasms against maize stem borer (Chilo partellus). The lower level of damage parameters (foliar damage, tunnel length and exit holes) were observed in genotypes namely R-POP-2, RML-5/RML-8, RampurSO3F8, RampurSO3FQ02 and RampurS10F18 revealing their suitability in MSB resistant breeding program of maize in Nepal. Further study is needed to confirm the resistant mechanism of the above genotypes.

\section{ACKNOWLEGEMENTS}

We express our sincere thanks and gratitude to Dr. Keshab Babu Koirala, Maize Coordinator for his active support and valuable suggestions during every stage of experimentation. We heartily acknowledge the breeding unit of NMRP, Rampur for providing the seeds for the experiment.

\section{REFERENCES}

Achhami, B.B., B.K., S.B., \& Bhandari, G.S. (2015). Assessment of maize stem borer damage on hybrid maize varieties in Chitwan, Nepal, Journal of Maize Research and Development, 1(1), 53-63.

Ampofo, J. K. O., \& Saxena, K. N. (1987). Screening Methodologies for Maize Resistance to Chilo partellus (Lepidoptera: Pyralidae). In: Toward Insect Resistant Maize for the Third World, Proceedings of the International Symposium on Methodologies for Developing Host Plant Resistance to Maize Insects, held at Mexico, D. F. CIMMYT, 170-177.

Attri, B.S., \& Sharma,P.L. (1968). Percentage Infestation by Chilo zonellus (Swinhoe) to Maize at Different Elevation in Himachal Pradesh. Indian Journal of Entomology, 30 (4), 317-318.

Chatterji, S.M., Young, W.R., Sharma,G.C. Sayi, I.V. , Chahal,B.S., Khare, B.P. Rathore, Y.S., Panwar,V.P.S., \& Siddiqui K.H. (1969). Estimation of Loss in Yield of Maize due to Insect Pests with Special Reference to Borers. Indian Journal of Entomology, 31, 109115.

Coppel, H.C., Chapman, R.K., \& Neupane, F.P. (1985). Monitoring the Maize Borer, Chilo partellus (Swinhoe) in Nepal through Light Trap and Life Table Studies. Nepalese Journal of Agriculture, 16, 85-92.

Kanta, U., Dhillon, B. S., \& Sekhon, S.S. (1994). Evaluation and Development of Maize Germplasm for Resistance to Spotted Stem Borer. Reviewed In: J.A. Mihm (ed) Insect 
Resistant Maize Recent Advances and Utilization Proceedings of an International Symposium held at Mexico, D.F.: CIMMYT, 246-254.

Klun, J. A., Guthrie, W. D., Halluauer, A. R., \& Russell, W. A. (1970). Genetic nature of the concentration of 2,4 dihydroxy-7-methoxy-(2H)-1,4-benzoxazin-3(4H)-one and resistance to European corn borer in a diallel set of eleven maize inbreeds. Crop Science, 10, 87-90.

Kumar, H. (1988). Effect of stalk damage on growth and yield of certain maize cultivars by the maize stalk borer Chilo partellus. Entomology Experimental Applied, 46(2),149-153

Kumar, H., \& Asino. G. O. (1993). Resistance of maize to Chile portellus (Lcpidoptera: Pyralidae): Effect of plant phenology. Journal of Economic Entomology 86. 969-973.

Lella, R., \& Srivastav, C. P. (2013). Screeing of maize genotypes against the stem borer Chilo partellus in kharif season. International Journal of Applied Biology and Pharmaceutical Technology,4(4), 394-403

McMullen, M. D., Monika, F., \& Jorg, D. (2009). Genetic and biochemistry of insect resistance in maize. In: Handbook of Maize: Its Biology, J. L. Bennetzen and S. C. Hake (eds), pp. 271-289.

MoAD (2014). Statistical information on Nepalese Agriculture. Government of Nepal, Ministry of Agricultural Development, Agri-Business Promotion and Statistics Division, Agri statistics Section, Singha Durbar, Kathmandu, Nepal.

Mohamed, H.M., Khan, Z.R., Overholt, W.A., \& Elizabeth, D.K. (2004). Behaviour and biology of Chilo partellus (Lepidoptera: Pyralidae) on maize and wild gramineous plants'. International Journal of Tropical Insect Science, 24, 287-297.

Munyiri, S.W., Mugo, S. N., Otim, M., Tefera, T., Beyene, Y., Mwololo, J. K., \& Okori, P. (2013). Responses of tropical maize landraces to damage by Chilo partellus stem borer. African Journal of Biotechnology, 12(11), 1229-1235. Available online at http://www.academicjournals.org/AJB DOI: 10.5897/AJB12.1802

Neupane, F.P., Chapman, R.K., \& Coppel, H.C. (1986). Temperature-developmental relationship of the maize borer, Chilo partellus (Swinhoe) (Lepidoptera:Pyralidae) in Nepal. Nepalese Journal of Agriculture, 17, 23-35.

Odiyi, O.P. (2007). Relationships between stem borer resistance and grain yield reduction in maize: Correlations, path analysis and correlated response to selection. Agriculture Journal, 2, 337-342.

Padhi, G. (2004). Biochemical basis of resistance in rice to yellow stem borer, Scirpophaga incertulas Walk. Madras Agricultural Journal, 91, 253-256.

Rajasekhar, L., \& Srivastav, C.P. (2013). Screening of maize genotypes against stem borer chilo partellus 1. In kharif season Institute of agricultural sciences, Banaras Hindu University. International Journal of Applied Biology and Pharmaceutical Technology Available online at www.ijabpt.com.

Sarwar, M. (2012). Management of rice stem borers (Lepidoptera: Pyralidae) through host plant resistance in early, medium and late plantings of rice (Oryza sativa L.). Journal of Cereals and Oil seeds, 3, 10-14. http://dx.doi.org.10.5897/JCO11.042

Sekhon, S.S., \& Kanta, U. (1994). Mechanisms and Bases of Resistance in Maize to Spotted Stem Borer. Reviewed In: J.A. Mihm (ed) Insect Resistant Maize Recent Advances and Utilization Proceedings of an International Symposium held at Mexico, D.F.: CIMMYT, 106-111. 
Sharma, M.L., \& Sharma, A.K. (1992). Comparative resistance of maize cultivars/inbreds to stem borer, Chilo partellus (Swin.) Insect Science, 5(2), 183-184.

Sharma, P.N., \& P. Gautam (2005). Resistance Screening of Maize Germplasms against Maize Stem Borer (Chilo partellus Swinhoe) in Nepal. Book of Abstracts. Ninth Asian Regional Maize Workshop (9 ${ }^{\text {th }}$ ARMW) Beijing, China, Sept.5-9, pp. 29.

Sharma, P.N., Thapa, R.B., Gautam, P., Giri, Y.P., Pathak, H.P., \& Aryal, S. (2007). Resistance Screening of Promising Maize Genotypes against Maize Stem Borer (Chilo partellus Swinhoe). Proceeding of the 25th National Summer Crop Research Workshop. National Maize Research Program, Nepal Agricultural Research Council (NARC), Kathmandu, Nepal. pp. 278-280.

Siddiqui, K.H. Singh, N.N. Panwar, V.P.S., \& Marwaha, K.K. (1996). Reaction of subtropical and tropical maize inbred lines to Chilo partellus (Swinhoe) and damage effect on silking, ear and plant heights. Indian Journal of Entomology, 57(3), 254-258.

Singh, B.U., Sharma, H.C., \& Rao, K.V. (2011). Mechanisms and genetic diversity for host plant resistance to spotted stem borer, Chilo partellus in sorghum, Sorghum bicolor. Journal of Applied Entomology, 135, 333- 392.

Songa, J.M., Mugo, S., Mulaa, M., Taracha, C., Bergvinson, D., Hoisington, D., \& Groote, H.D. E. (2002). Towards development of environmentally safe insect resistant maize varieties for food security in Kenya. Paper presented to the symposium on: Perspectives on the evolving role of private/public collaborations in agricultural research. Organized by the Syngenta foundation for Sustainable Agriculture, Washington, D.C., USA.

Thakur, P., Shrestha, J., Bhandari, G. S., \& Achhami, B. B. (2013). Insect scenario and its succession in year round weekly interval seeded maize varieties at Rampur, Chitwan, Nepal, International Journal of Modern Plant \& Animal Sciences, 1(2), 96-104.

Upadhyay, S.R., Sharma, D., Mahato, R.K., Paudel, D.C., Koirala, K.B., Parsad, R.C., Shah, S.N., Katuwal, R.B., Pokhrel, B.B., Dhakal, R., \& Dhami, N.B. (2007). Development of QPM (Quality Protein Maize) Varieties for the Hills of Nepal. Proceedings of the 25th National Summer Crops Research Workshop, National Maize Research Program, Nepal Agricultural Research Council, Kathmandu, Nepal. pp.31-38. 